\title{
Mesenchymal Stem or Stromal Cells: Toward a Better Understanding of Their Biology?
}

\author{
Ulrich Lindner $^{a} \quad$ Jan Kramer $^{a, b} \quad$ Jürgen Rohwedel ${ }^{b} \quad$ Peter Schlenke $^{c}$ \\ a Medical Department I, Division of Nephrology and Transplantation Unit, \\ ${ }^{\mathrm{b}}$ Department of Virology and Cell Biology, University of Lübeck, \\ ${ }^{c}$ Institute of Transfusion Medicine und Transplantation Immunology, Westphalian Wilhelms-University Münster, Germany
}

\section{Key Words}

MSC · Differentiation - Stem cells · Pericytes ·

Fibroblasts

\section{Summary}

The adult bone marrow has been generally considered to be composed of hematopoietic tissue and the associated supporting stroma. Within the latter compartment, a subset of cells with multipotent differentiation capacity exists, usually referred to as mesenchymal stem cells. Mesenchymal stem cells can easily be expanded ex vivo and induced to differentiate into several cell types, including osteoblasts, adipocytes and chondrocytes. Up to now, mesenchymal stem cells have gained wide popularity. Despite the rapid growth in this field, irritations remain with respect to the defining characteristics of these cells, including their differentiation potency, self-renewal and in vivo properties. As a consequence, there is a growing tendency to challenge the term mesenchymal stem cell, especially with respect to the stem cell characteristics. Here, we revisit the experimental origins of mesenchymal stem cells, their classical differentiation capacity into mesodermal lineages and their immunophenotype in order to assess their stemness and function. Based on these essentials, it has to be revisited if the designation as a stem cell remains an appropriate term.

\section{Introduction}

In the last decade great interest has been focused on human mesenchymal stem cells (MSCs) because of their differentiation potential into mesodermal cell types including the classi-

\section{Schlüsselwörter}

MSC · Differenzierung · Stammzellen · Perizyten · Fibroblasten

\section{Zusammenfassung}

Generell wird davon ausgegangen, dass sich das Knochenmark aus hämatopoetischen Gewebe und dem unterstützenden Stroma zusammensetzt. Bestandteil des Stroma ist eine Population von Zellen mit multipotenter Differenzierungskapazität, die üblicherweise als mesenchymale Stammzellen bezeichnet werden. Mesenchymale Stammzellen können leicht ex vivo expandiert und zur Differenzierung in verschiedene (mesodermale) Zelltypen wie z.B. Osteoblasten, Adipozyten und Chondrozyten induziert werden. Trotz des wachsenden Interesses an den mesenchymalen Stammzellen fehlen bislang Erkenntnisse über die grundlegenden Charakteristika dieser Zellen - z.B. ihr Differenzierungspotential, die Mechanismen der Selbsterneuerung sowie ihre In-vivo-Eigenschaften und Herkunft. Aufgrund dieser Einwände wird die Bezeichnung als mesenchymale Stammzelle zunehmend in Frage gestellt. In diesem Artikel werden die Geschichte, das klassische mesodermale Differenzierungspotential und der Immunphänotyp der mesenchymalen Stammzelle beleuchtet. Anhand dieser wesentlichen Grundlagen soll diskutiert werden, ob der Begriff mesenchymale Stammzelle angemessen ist.

cal tri-lineage potential of adipogenesis, chondrogenesis and osteogenesis [1, 2]. Additional plasticity for differentiation of MSCs into cardiogenic and myogenic as well as non-mesodermal cell types such as neuronal cell has been postulated [3-5]. However, this non-lineage restricted transdifferentiation pat-

\section{KARGER}

Fax +497614520714

Information@Karger.de

www.karger.com (c) 2010 S. Karger GmbH, Freiburg

Accessible online at:

www.karger.com/tmh 
tern may also be explained by mechanisms such as dedifferentiation or cell fusion [6-8].

Historically MSCs were derived from human bone marrow (BM) $[1,9]$. Actually, tissue resident cells with characteristics of MSCs have been isolated from other than BM tissues like umbilical cord blood [10], adipose tissue [11], salivary glands [12], and from human organs like the gut [13]. Despite the terminology routinely applied, whether MSCs might fulfill the minimal criteria of 'true' stem cells remains a legitimate question. In contrast to hematopoietic stem cells (HSCs), which can repopulate the $\mathrm{BM}$ and differentiate into all blood types [14], and embryonic stem cells (ESCs), which take part in embryonic development of all tissues after re-injection into early embryos [15], no comparable in vivo tests have been established for MSCs. Recovery of MSCs mostly have been performed by simple plastic adherence and the assessment of morphological criteria such as the fibroblastoid phenotype. This procedure resulted in a heterogeneous population which contain both single stem cell-like cells as well as progenitor cells with different lineage commitment (fig. 1). Due to the lack of a unique MSC function, these populations were termed 'mesenchymal stem cells' or synonymously 'marrow stromal cells', 'BM stromal cells' and 'mesenchymal stromal cells' [16-18]. Due to specific features which indicate more primitive subsets of MSCs with a higher differentiation capacity [reviewed in 19], some authors described the cells as 'multipotent adult progenitor cells' (MAPC) [20], 'marrowisolated adult multilineage inducible cells' (MIAMI) [21] or 'multipotent adult stem cells' (MASC) [22].

Despite increasing interest in fundamental research and its translation into clinical applications in recent years, the understanding of MSC biology remains rudimentary. At the moment, the physiological features of MSCs in vivo are not completely understood, since most of the insights are based on indirect evidence, mainly from in vitro studies dealing with MSC cultures. Currently, MSCs are still identified by a combination of in vitro observed morphological, immune phenotypical and differentiation characteristics including their classical tri-lineage differentiation capacity $[23,24]$. The entire field is lacking strong data supporting engraftment and functional in vivo integration of MSCs [reviewed in 25]. Therefore, in vivo cell imaging to determine the tissue-specific location and migration of MSCs might help to better understand MSC biology and their in vivo 'niche' [114]. For example, in vivo tracking of MSCs might also result in a better understanding of regenerative techniques which use direct in vivo guidance of the cells to a defect without previous in vitro culture [26].

\section{History of Mesenchymal Stem Cells}

Non-hematopoietic, 'mesenchymal' precursor cells derived from BM were first described by Friedenstein et al. at the beginning of 1970s [27, 28], who isolated BM followed by an in

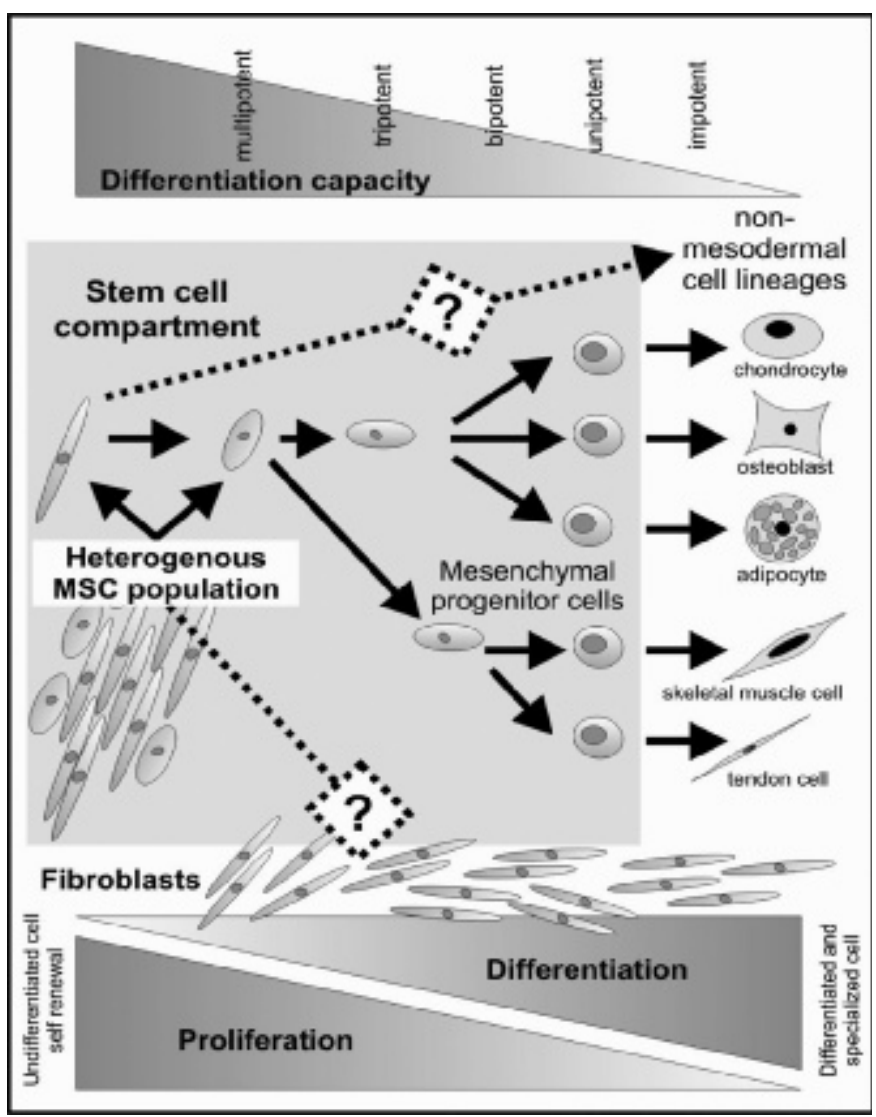

Fig. 1. MSC biology still demands some answers. MSC population isolated by simple plastic adherence are heterogeneous. The classical stem cell compartment is the bone marrow. For the bone marrow as well as the periphery of the body a perivascular location of undifferentiated MSCs was suggested and pericytes may be a cellular in vivo equivalent of in vitro characterized MSCs. It has also been demonstrated that fibroblasts share many characteristics with MSCs evoking the question if these cells may be another in vivo counterpart of MSCs. In addition, clear evidence for the transdifferentiation capacity of MSCs is missing. The recent view in stem cell biology is that not plasticity of MSCs but paracrine action after their application is mostly responsible for in vivo effects overlapping lineage restriction.

vitro incubation in a humidified atmosphere using plastic tissue culture flasks. After a few days a heterogeneous population of adherent cells was observed. Within the first days of cultivation, small colonies of fibroblastoid cells appeared, surrounded by other mononuclear cell types. In this assay system, fibroblastoid cells were referred to as colony forming unit fibroblasts (CFU-F). The physiological impact of CFU-F in vivo was initially reduced to the support of hematopoiesis [29].

Based on these findings, Owen [30] suggested in 1985 the existence of 'stromal' stem cells, residing in their own niche and with the ability to self-renew and to generate mature 'stromal' cells. The BM stroma or such 'stroma' cells produce extracellular matrix proteins and additional soluble substances for the support of hematopoiesis and to complete the hematopoietic stem cell niche in its entirety. 
Table 1. Human

MSCs derived from different sources

\begin{tabular}{ll}
\hline Tissue (human) & References $^{\mathrm{a}}$ \\
\hline Adipose & {$[6,85-89]$} \\
Cartilage & {$[90,91]$} \\
Cord blood & {$[92-95]$} \\
Dental pulp & {$[96-99]$} \\
Gut & {$[13]$} \\
Perichondrium & {$[100]$} \\
Salivary glands & {$[12]$} \\
Tendon & {$[101]$}
\end{tabular}

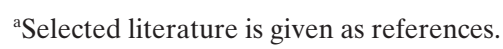

In the 1980s further work made clear that the cells identified by Alexander Friedenstein and colleagues were multipotent in the sense that they give rise to osteoblasts, chondrocytes and adipocytes [17]. The frequency of CFU-F or 'stromal' stem cells was investigated for different species and sources and seemed to be dependent on the culture conditions and experimental settings performed [2, 17]. Furthermore, different external factors like growth factors and culture media were explored for its influences on the frequency and size of CFU-Fs. Platelet derived growth factor (PDGF), epidermal growth factor (EGF), basic fibroblast growth factor (bFGF), transforming growth factor-beta (TGF- $\beta$ ), and insulin-like growth factor 1 (IGF-1) were tested positive for proliferation of CFU-F [31-35].

Based on Friedenstein's studies on the origins of these cells in the BM, Caplan [36-38] delineated the mesengenic process of cellular differentiation from immature rather stem and progenitor cells to multiple mature cell types of the mesodermal lineages (e.g. adipocytes, chondrocytes, osteoblasts). In this way, Caplan introduced the term 'mesenchymal stem cell' to describe these cells with stem cell-like feature. Mesenchyme originally describes the embryonic loose connective tissue that is derived from the mesoderm and that develops into hematopoietic and connective tissue.

The term 'mesenchymal stem cell' is controversially discussed. Some investigators in the field prefer the term 'mesenchymal stromal cell', especially because the stem cell 'label' seems at least not always appropriate, especially for connective tissue cells that form the supportive structure (scaffold) of an organ [39]. Particularly, the relationship of MSCs to other stromal cells like fibroblasts is still discussed [reviewed in 40]. Both fibroblasts and MSCs show a spindle shaped morphology and express the panel of $\mathrm{CD}$ marker molecules which is required according to the minimal criteria of MSCs [41, 42]. Multipotent differentiation of fibroblasts has also been reported [43, 44]. Moreover, fibroblasts represent a diverse population of cells increasing the complexity of stromal cell biology. In fact, MSCs and fibroblasts are dynamic cells from at least the same lineage. These proliferating cells might also share the capacity of deand redifferentiation, which means that overlapping biological impact of both cell types is possible.

After Friedenstein and colleagues [45] described the presence of multipotent MSCs in thymus and other lymphoid organs, MSCs were also isolated from other tissues than BM, e.g. from adipose tissue, cartilage, salivary glands or cord blood (table 1). As another source also the peripheral blood is discussed [reviewed in 46]. Depending on the source and the native or cultivated state of the MSC population characterized, differences were observed in regard to the immunophenotype, cytokine profile, and results obtained by proteome analysis [47-49]. Despite of attempts for establishing generally acceptable minimal criteria for defining human MSCs by immunophenotyping, the functional capability to differentiate along the classical tri-lineage mesodermal pathways remains one fundamental criterium of this cell type.

\section{In vitro Mesodermal Differentiation Potential of Mesenchymal Stem Cells}

The in vitro differentiation of MSCs into the three classical lineages is easily achieved. Representative samples of inductive reagents employed in a number of studies are shown in table 2. Determination of the phenotype of differentiated cells depends on morphological, immunophenotypical and functional criteria. For example, adipocytes are easily identified by their morphology and staining with Oil Red O (fig. 2). For adipogenesis, the most employed agents are those that increase the intracellular levels of second messenger cyclic adenosine monophosphate (cAMP), e.g. methylisobutylxanthine. Other substances such as dexamethasone are ligands of glucocorticoid receptors and the peroxisome proliferator activated receptor gamma (PPAR $\gamma)$. Therefore, for the confirmation of adipogenesis expression of PPAR $\gamma$ is detected via biochemical assays [50]. Other gene markers which have been used for detection of MSCs differentiated into adipocytes are fatty acid binding protein 4 and lipoprotein lipase. Furthermore, the secretion of adiponectin and leptin could be measured [51-53].

The differentiation into osteoblasts is determined by upregulation of alkaline phosphatase activity and deposition of a mineralized extracellular matrix. The mineralized matrix can be detected with Alizarin Red or von Kossa stain (fig. 2). Additional biochemical assays detect alkaline phosphatase activity or secreted osteocalcin $[54,55]$. Further osteogenic marker proteins are bone sialoprotein and osteopontin, which are also proved using biochemical assays [56]. Differentiation into osteoblastic lineage can be also detected by changes of cell surface expression of STRO-1 and alkaline phosphatase antigen during the in vitro development to osteoblasts $[57,58]$.

Chondrogenesis is most effectively, when 3D models are used. Therefore, MSCs were centrifugated to form pellets (so-called micromass bodies), or cells are embedded in hydrogel like agarose or alginate [59,60]. Recently, a cell saving cultivation method via so-called mesenchymal microspheres has been demonstrated to be beneficial for chondrogenic as 
Table 2. In vitro mesenchymal lineage differentiation potential of MSCs into adipocytes, chondrocytes and osteoblasts after application of inductive factors

\begin{tabular}{lll}
\hline Lineage & Inductive factors & References \\
\hline Adipocytes & $\begin{array}{l}\text { dexamethasone, } \\
\text { indomethacine, } \\
\text { insulin, } \\
\text { methylbutylxanthine, } \\
\text { thiazolidinedione }\end{array}$ & \\
& [50,102-104] & \\
\hline Chondrocyte & $\begin{array}{l}\text { ascorbate, } \\
\text { bone morphogenic protein 6, } \\
\text { dexamethasone, } \\
\text { transforming growth factor } \beta\end{array}$ & \\
\hline Osteoblast & $\begin{array}{l}\text { ascorbate, } \\
\text { bone morphogenetic protein, } \\
\text { dexamethasone, } \\
\text { 1,25 dihydroxy vitamin D 3 }\end{array}$ & \\
\hline
\end{tabular}

${ }^{\text {a }}$ Selected literature presenting current differentiation procedures is shown.

well as adipogenic and osteogenic differentiation of MSCs [61]. Chondrogenesis is histochemically detected by toluidine blue or safranin-O staining, after micromass bodies were embedded in paraffin and cut in ultrafine sections. Proteoglycans can be detected as indicator for chondrogenesis using the safranin $\mathrm{O}$ or toluidine blue based staining procedure. Furthermore, chondrogenesis can also be verified by biochemical assays for the detection of glycosaminoglycan content or collagen IX and versican. MSCs which were induced into the chondrogenic pathway need also to synthesize the major cartilageneous proteins collagen II and aggrecan in sufficient quantities. This is an essential attribute in order to use MSCs for muscoloskeletal repair [62]. Chondrogenesis can be enhanced by placing the cells into synthetic scaffolds [63]. Other factors, which may play essential roles for the regulation of chondrogenesis and the quality of tissue obtained after differentiation are extracellular matrix, mechanical stimuli and hypoxia [64-66].

In vitro cultured MSCs show great heterogeneity with respect to their differentiation potential (fig. 1). Although investigations in established MSC cultures show them to be multipotent, with a tri-lineage differentiation potential, in clonal assays it could be observed that only one third of these MSCs are multipotent [67]. Thus, a minority of cells seems to be multipotent, with most of them having bi- or only uni-lineage differentiation capacity. It is hypothesized that the heterogeneous MSC population contains a small pool of immature cells with tri-lineage multipotency. Other isolated MSCs have lost their tri-lineage multipotency while passing through different stages of maturation, ending with an only unipotent differentiation capacity (fig. 1) [17, 67]. On the other hand, it is hypothesized that reagents used for induction of adipogen-

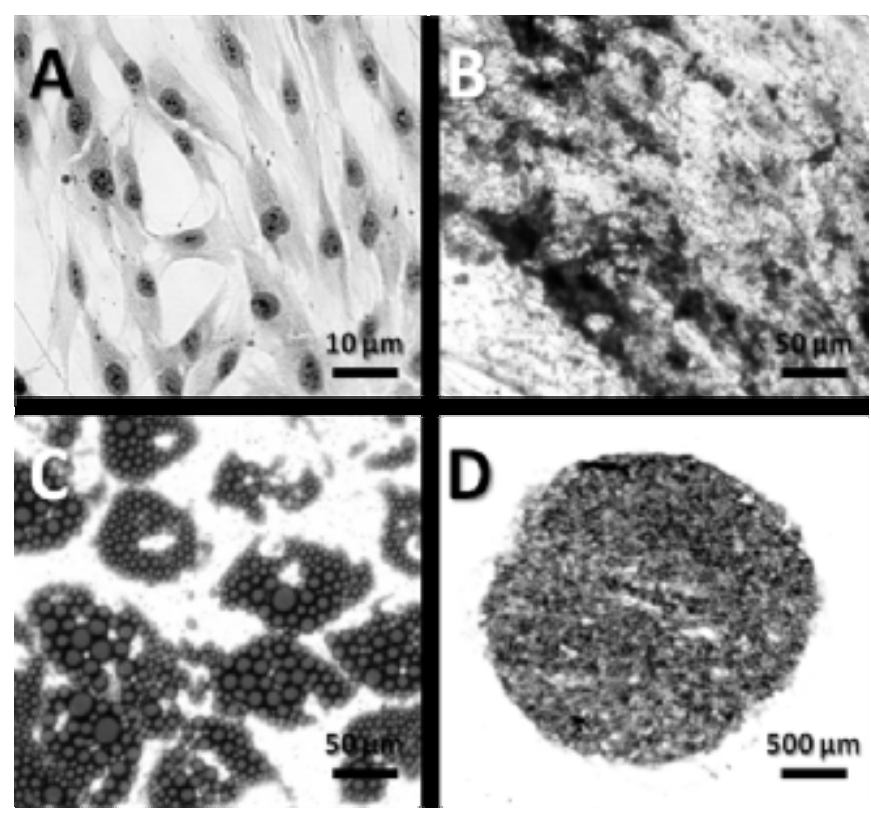

Fig. 2. A The Giemsa staining demonstrates a typical fibroblastoid shape of undifferentiated MSCs. After application of specific induction media the MSCs are capable to differentiate into B osteoblasts (von Kossa stain and counterstaining with van Gieson), C adipocytes (Oil Red O stain) and $\mathbf{D}$ chondrocytes (toluidine blue stain) using 3D cultivation via micromass bodies.

esis inhibit osteogenesis and vice versa [68, 69]. Furthermore, it is known that PPAR $\gamma$ ligands have inhibitory effects on osteogenesis while alendronate have stimulating effects on osteogenesis and simultaneously suppresses adipogenesis [70, 71]. In contrast, other ligands were detected having stimulating effects on both lineages [72]. Thus, further investigations concerning reciprocal influences of lineage pathways are needed.

\section{Phenotyping and Isolation of Mesenchymal Stem Cells}

Flow cytometry is a powerful and easy to handle approach for immunophenotyping of cells using fluorescence labeled monoclonal antibodies (mAbs) against cell surface antigens. The cell surface antigen profile of MSCs has been well explored, and in recent years various combinations of cell surface markers were published for characterizing MSCs of different sources and species [73] (table 3). However, no unique and specific marker has been described to adequately define MSCs exclusively, and in scientific practice it is still required to define MSCs by their differentiation capacity [23]. Over the years, a lot of attempts were made to define international minimal standards for the characterization of MSCs by flow cytometry based immunophenotyping. For example, as part of minimal criteria proposed by the Mesenchymal and Tissue Stem Cell Committee of the International Society for Cellular Therapy MSCs must be positive for CD105, CD73, and CD90 
Table 3. Selected cell surface antigens expressed on human bone-marrow derived MSCsa

\begin{tabular}{|c|c|c|c|}
\hline $\begin{array}{l}\mathrm{CD} \text { (cluster of } \\
\text { differentiation) }\end{array}$ & Molecule & MSCs & References \\
\hline $11 \mathrm{a}$ & integrin $\alpha \mathrm{L}$ chain & - & {$[1]$} \\
\hline $11 b^{*}$ & integrin $\alpha \mathrm{M}$ chain & - & [110] \\
\hline 13 & aminopeptidase $\mathrm{N}$ & + & [111] \\
\hline $14^{*}$ & & - & [1] \\
\hline $19 *$ & & - & [1] \\
\hline 29 & integrin $\beta 1$ chain & + & [1] \\
\hline $34 *$ & & - & [1] \\
\hline 44 & hyaluronan receptor & + & [1] \\
\hline $45^{*}$ & & - & [1] \\
\hline $49 \mathrm{a}$ & integrin $\alpha 1$ chain & + & [1] \\
\hline $49 b$ & integrin $\alpha 2$ chain & + & [1] \\
\hline $49 \mathrm{c}$ & integrin $\alpha 3$ chain & + & [1] \\
\hline $49 \mathrm{~d}$ & integrin $\alpha 4$ chain & + & [1] \\
\hline $49 \mathrm{e}$ & integrin $\alpha 5$ chain & + & [1] \\
\hline 51 & integrin $\alpha v$ chain & + & [1] \\
\hline 54 & ICAM-1 & + & [1] \\
\hline 58 & LFA-3 & + & [1] \\
\hline 61 & integrin $\beta 3$ chain & + & [1] \\
\hline $62 \mathrm{~L}$ & L-selectin & + & [1] \\
\hline 71 & transferrin receptor & + & [1] \\
\hline $73 *$ & ecto-5'-nucleotidase & + & [1] \\
\hline $79 a^{*}$ & & - & [1] \\
\hline $90 *$ & Thy-1 & + & [1] \\
\hline 102 & ICAM-2 & + & [1] \\
\hline 104 & integrin $\beta 4$ chain & + & [1] \\
\hline $105^{*}$ & endoglin: TGF- $\beta$ R III & + & [1] \\
\hline 106 & VCAM-1 & $+/-$ & [1] \\
\hline 109 & & + & [111] \\
\hline 117 & c-KIT / SCFR & - & [111] \\
\hline $120 \mathrm{a}$ & TNF IR & + & [1] \\
\hline $120 \mathrm{~b}$ & TNF IIR & + & [1] \\
\hline 121a & IL-1R & + & [1] \\
\hline 123 & IL-3R $\alpha$ & + & [1] \\
\hline 124 & IL-4R & + & [1] \\
\hline 126 & IL-6R & + & [1] \\
\hline 127 & IL-7R & + & [1] \\
\hline 133 & $\mathrm{AC} 133$ & - & [111] \\
\hline 140a & PDGF-R / PDGFR $\alpha$ & + & [111] \\
\hline $140 \mathrm{~b}$ & PDGFR $\beta$ & - & [111] \\
\hline 146 & MUC18, S-endo & + & [112] \\
\hline 271 & NGFR & $-1+$ & {$[113]$} \\
\hline
\end{tabular}

aThe designation $(+)$ or $(-)$ indicates presence or absence of markers. *Antigens are part of the minimal criteria proposed by the Mesenchymal and Tissue Stem Cell Committee of the International Society for Cellular Therapy. CD 271 is highly expressed on subsets of fresh isolated MSCs, while marker expression is lacking after a short period of in vitro cultivation.

and negative for CD45, CD34, CD14 or CD11b, CD79a, or CD19, and HLA-DR [39]. However, none of these markers or marker combinations seems to be a reliable parameter for characterizing the stemness of each investigated MSC population or being suitable to gain purity of MSC culture. Factors such as culture conditions, especially in long-term in vitro cultures, may influence the homogeneous growth of MSCs and cause a pattern of heterogeneity in MSC outgrowth, which might expressed by artificial or physiological maturation of MSCs to a still undefined extent. For that reasons MSC cultures generated from different species, by different isolation procedures or under different cultivation conditions might express similar but not necessarily identical cell surface marker profiles. Thus comparability of studies is hard to assess, and conclusions have to be carefully balanced.

Another focus is the identification of markers allowing the prospective isolation of MSC subpopulations with rather multipotential differentiation capacity from fresh tissue. The best known MSC marker, STRO-1, was used for the enrichment of such immature cells from BM derived MSCs. However, its exclusiveness could not be confirmed [24]. Other attempts included magnetic cell separation or fluorescence activated cell sorting (FACS) using different cell surface markers such as CD49b, CD105, CD73, CD200, CD271, SSEA-1 and SSEA-4 [reviewed in 73, 74]. However, all these markers are also expressed on other cell types. Thus, antibody based isolation of MSCs may be a valuable tool for an initial step of pre-enrichment of MSCs, but cannot guarantee for purity of in vitro expanded MSCs or the disadvantageous exclusion of an important MSC subpopulation.

A frequently described marker is the low affinity NGF receptor (NGFR/CD271) used for the purification of MSCs from BM mononuclear cells [75-77]. This glycoprotein, although expressed in the nervous system, has been detected on melanocytes, monocytes and lymphocytes. CD271+ cells are able to differentiate into multiple mesenchymal lineages. As reported by Jones et al. [76] CD271 seems to be the most appropriate marker for the isolation and enrichment of BM derived MSCs. This marker is highly expressed on MSCs in vivo and selected MSCs from cell types also expressing hematopoietic markers [76]. Using additionally D7-FIB (a fibroblastoid surface antigen with unknown function) and CD45 (hematopoietic marker), rather multipotent MSCs were isolated that can give rise to different mesenchymal lineages [75]. Thus, CD271 may become the attribute of a relatively specific and selective marker for native MSC purification which limits the degree of contaminations by other cells.

\section{Is 'Mesenchymal Stem Cell' a Proper Term?}

Despite the terminology routinely applied, whether MSCs qualify as 'stem cells' remains a legitimate question. ESCs generated from early stages of embryonic development before gastrulation takes place (blastocyst) are pluripotent stem cells since these cells have the capacity to differentiate into all different cell types of an organism. In contrast, adult stem cells usually feature a more restricted spectrum of differentiation. The best known and examined adult stem cell popula- 
tion are the HSCs. HSCs are defined by their potential - on a single cell level - to in vivo regenerate and maintain the blood, reflecting their lineage restriction [78, 79]. Actually, multipotent HSCs are able to produce all blood and immune cells in its complexity under steadystate hemostasis as well as on stress induced demand for a lifetime. This HSC property is biologically linked to a tightly regulated balance between selfrenewal of still multipotent daughters and their differentiation induction into lineage-committed progenitor cells.

Based on this conservative and strict definition of 'true' stem cells, it is currently not possible to confirm that MSCs fulfill these properties. First, an at least time limited or lifelong self-renewal capacity of human MSCs could not be proven. Moreover, the inductive in vitro differentiation capacity of MSCs after application of induction media is not comparable to the hematopoietic repopulation which takes place in NOD/ SCID mice after transplantation of 'true' HSCs.

Thus, some of the inherent biological properties of the HSC concept are not necessarily transferable to other adult stem cells. For example, HSCs can be transplanted in vivo via circulation and distributed highly effective without in vitro culture. The regeneration of a skeletal defect requires a local transplant, and therefore skeletal progenitors have to be isolated and in vitro expanded. Furthermore, the capacity of selfrenewal relates just to the rate of tissue turnovers. For example, the whole skeleton turns over 3-5 times during adulthood. Thus, considering self-renewal and multipotency for defining characteristics of adult stem cells requires the development of an in vivo assay based on the same strict principles as it is used for defining HSCs. But it should be adapted to the specific biology of the cell type under study. Such studies are of utmost importance also for prospective therapeutic approaches in regenerative medicine, particularly in order to verify any already today promised clinical applicability of MSCs.

Up to now, stem cell-like characteristics of MSCs were primarily evidenced using indirect systems such as experiments using in vitro cultivation of BM mononuclear cells or other tissue derived cells. The primary in vitro culture only includes a subset of MSCs with multipotency [80, 81]. Several attempts were made to isolate this subset of MSCs by immunophenotyping as reported above. Thus far, no markers are available to distinguish multipotent MSCs from more committed progenitor cells. So, most information is derived from in vitro studies based upon BM cells being 'heterogeneous' with respect to the specific markers expressed on their cell surface. In these in vitro approaches, MSCs were also usually exposed to culture conditions that are far different from those present in their in vivo stem cell niche. Consequently, it is difficult to compare the results from these in vitro studies with the in vivo situation. The above mentioned complex phenotype becomes even more diverse if one takes into account that some of the antigens are down- or up-regulated on MSCs (sub)populations during in vitro cultivation, adding further complexity to experimental findings.
Because the experimental proof whether MSCs or even their subsets fulfill the stem cell definition is still lacking - on a single cell level -, the term 'stem cell' seems to be inappropriate. Furthermore, ex vivo generated MSCs are a heterogeneous population, containing only a fraction of cells with selfrenewal potential and multipotency [82]. Thus, we prefer the term 'mesenchymal stromal cells', as proposed by the International Society for Cellular Therapy [83]. The term 'stroma cells' describe connective tissue cells that form the supportive structure in which the functional cells of the tissue reside. This is an accurate description for one function of MSCs [29].

Furthermore, because of the heterogeneity of the MSC population and different isolation techniques used among laboratories, the characteristics defining MSCs are inconsistent. This results in the inability to compare studies from different groups. In addition, investigators have isolated MSCs from different sources [14]. To adequately compare the biological properties and experimental reports on MSCs, we also refer to the consensus minimal criteria for defining "mesenchymal stromal cells'. This definition implies as criteria: i) the adherence to plastic, ii) the expression of specific surface antigens and iii) the in vitro differentiation into the classical tri-lineage pathways. More than $95 \%$ of the MSC population must express CD105, CD73 and CD90, as measured by flow cytometry. Additionally, these cells must lack expression $(<2 \%$ positive) of CD45, CD34, CD14 or CD11b, CD79 $\alpha$ or CD19 and HLA class II (HLA-DR; table 3 ) in order to exclude HSC contaminations.

Alternative approaches for experimental investigations close to in vivo conditions are necessary to detect MSCs with multipotency in in vitro stem cell cultivation. Besides the biological availability of a highly specific single marker for the detection and isolation and expansion of MSCs, novel technologies are highly desired to expand MSCs in a relatively non-manipulated state on large scale for clinical proposes. This topic is depicted in more detail by Freimark et al. [115] in this issue.

Another obstacle to the study of MSCs is the lack of precise knowledge regarding their in vivo identity. This is a prerequisite for designing an in vivo assay for MSCs. It is proposed that the perivascular compartment is a MSC stem cell niche, indicating that MSCs can be characterized as pericytes $[24,82]$. Pericytes reside in the microvessels of every connective tissue. Therefore, some authors suggest that the wide distribution of pericytes as in situ counterpart of MSCs explains why MSCs can be isolated from different tissues [74]. On the other hand, pericytes isolated from skeletal muscle are spontaneously myogenic and non-osteogenic [84]. The identification of the in vivo identity of MSCs will be another key result toward the therapeutical implementation of this promising cell type. Therefore, further studies of pericytes' biology may provide clues to the in vivo identity of MSCs in the future. 


\section{Conclusions}

Up to now, it is impossible to identify and enrich a subset of the heterogeneous pool of MSCs, which could be functionally probed in vivo in order to confirm their stem cell characteristics. Until suitable markers will become available for the detection and isolation of such a subset, MSCs will represent a heterogeneous pool of cells with the only assured in vivo function of providing a microenvironment for other stem cells. Taken these facts into consideration, the term mesenchymal stromal cell is a proper and superior designation, expressing at least one approved in vivo function of this cell type. Ultimately, it would be desirable for the future that our current, fragmented knowledge about mesenchymal stromal cell bio- logy could be linked to an anatomically recognizable cell type in situ. Pericytes or fibroblasts found in different tissues are possible candidates.

\section{Acknowledgements}

The work of J.K. was supported by the Medical Faculty of the University of Lübeck (Junior Research Cluster: Epithelial Inflammation) and Intermed Service GmbH and Co. KG (Geesthacht, Germany).

\section{Disclosure}

The authors declared no conflict of interest.

\section{References}

1 Pittenger MF, Mackay AM, Beck, SC, Jaiswal RK, Douglas R, Mosca JD, Moorman MA, Simmonetti DW, Craig S, Marshak DR: Multilineage potential of adult human mesenchymal stem cells. Science 1999;284:143-147.

2 da Silva Meirelles L, Chagastelles PC, Nardi NB: Mesenchymal stem cells reside in virtually all postnatal organs and tissues. J Cell Sci 2006;119:2204 2213.

3 Ferrari G, Cusella-De Angelis G, Coletta M, Paolucci E, Stornaiuolo A, Cossu G, Mavilio F: Muscle regeneration by bone marrow-derived myogenic progenitors. Science 1998;279:1528-1530.

4 Makino S, Fukuda K, Miyoshi S, Konishi F, Kodama H, Pan J, Sano M, Takahashi T, Hori S, Abe H, Hata J, Umezawa A, Ogawa S: Cardiomyocytes can be generated from marrow stromal cells in vitro. J Clin Invest 1999;5:697-705.

$\checkmark 5$ Hakuno D, Fukuda K, Makino S, Konishi F, Tomita Y, Manabe T, Suzuki Y, Umezawa A, Ogawa $\mathrm{S}$ : BM-derived regenerated cardiomyocytes (CMG cells) express functional adrenergic and muscarinic receptors. Circulation 2002;105:380-386.

6 Franco Lambert AP, Fraga Zandonai A, Bonatto D, Cantarelli Machado D, Pêgas Henriques JA: Differentiation of human adipose-derived adult stem cells into neuronal tissue: does it work? Differentiation 2009;77:221-228.

$\checkmark 7$ Schäfer R, Northoff H: Cardioprotection and cardiac regeneration by mesenchymal stem cells. Panminerva Med 2008;50:31-39.

$>8$ Wagers AJ, Weissman IL: Plasticity of adult stem cells. Cell 2004;116:639-648.

$\checkmark$ Mackay AM, Beck SC, Murphy JM, Barry FP, Chichester CO, Pittenger MF: Chondrogenic differentiation of cultured human mesenchymal stem cells from marrow. Tissue Eng 1998;4:415-428.

$\checkmark 10$ Lee KL, Kuo TK, Chen WM, Lee KD, Hsieh SL, Chen TH: Isolation of multi-potent mesenchymal stem cells from umbilical cord blood. Blood 2003; 103:1669-1675.

11 Kern S, Eichler H, Stoeve J, Klüter H, Bieback K Comparative analysis of mesenchymal stem cells from bm, umbilical cord blood, or adipose tissue. Stem Cells 2006;24:1294-1301.

12 Rotter N, Oder J, Schlenke P, Lindner U, Böhrnsen F, Kramer J, Rohwedel J, Huss R, Brandau S, Wollenberg B, Lang S: Isolation and characterization of adult stem cells from human salivary glands. Stem Cells Dev 2008;17:509-518.
13 Lanzoni G, Alviano F, Marchionni C, Bonsi L, Costa R, Foroni L, Roda G, Belluzzi A, Caponi A, Ricci F, Luigi Tazzari P, Pagliaro P, Rizzo R, Lanza F, Roberto Baricordi O, Pasquinelli G, Roda E, Paolo Bagnara G: Isolation of stem cell populations with trophic and immunoregulatory functions from human intestinal tissues: potential for cell therapy in inflammatory bowel disease. Cytotherapy 2009:8:1020-1031.

14 Moore KA, Lemischka IR: Stem cells and their niches. Science 2006;311:1880-1885.

15 Bradley A, Evans M, Kaufman MH, Robertson E: Formation of germ-line chimaeras from embryoderived teratocarcinoma cell lines. Nature 1984; 309:255-256.

16 Baksh D, Song L, Tuan RS: Adult mesenchymal stem cells: characterization, differentiation, and application in cell and gene therapy. J Cell Mol Med 2004:8:301-316.

17 Prockop DJ: Marrow stromal cells as stem cells for nonhematopoietic issues. Science 1997;276:71-74.

18 Schäfer R, Dominici M, Müller I, Dazzi F, Bieback K, Godthardt K, Le Blanc K, Meisel R, Pochampally R, Richter R, Skutella T, Steinhoff G, Mitterberger M, Wendel H, Wiskirchen J, Handgretinger R, Northoff H: Progress in characterization, preparation and clinical applications of nonhematopoietic stem cells, 29-30 September 2006, Tübingen, Germany. Cytotherapy 2007;9:397-405.

19 Ratajczak MZ, Zuba-Surma EK, Wysoczynski M, Wan W, Ratajczak J, Wojakowski W, Kucia M: Hunt for pluripotent stem cell - regenerative medicine search for almighty cell. J Autoimmun 2008; 30:151-62.

20 Jiang Y, Jahagirdar BN, Reinhardt RL, Schwartz RE, Keene CD, Ortiz-Gonzalez XR, Reyes M, Lenvik T, Lund T, Blackstad M, Du J, Aldrich S, Lisberg A, Low WC, Largaespada DA, Verfaillie CM: Pluripotency of mesenchymal stem cells derived from adult marrow. Nature 2002;418:41-49.

21 D'Ippolito G, Diabira S, Howard GA, Menei P, Roos BA, Schiller PC: Marrow-isolated adult multilineage inducible (MIAMI) cells, a unique population of postnatal young and old human cells with extensive expansion and differentiation potential. J Cell Sci 2004;117:2971-2981.
22 Beltrami AP, Cesselli D, Bergamin N, Marcon P, Rigo S, Puppato E, D'Aurizio F, Verardo R, Piazza S, Pignatelli A, Poz A, Baccarani U, Damiani D, Fanin R, Mariuzzi L, Finato N, Masolini P, Burelli S, Belluzzi O, Schneider C, Beltrami CA: Multipotent cells can be generated in vitro from several adult human organs (heart, liver, and bone marrow). Blood 2007;110:3438-3446.

23 Kolf CM, Cho E, Tuan RS: Mesenchymal stromal cells. biology of adult stem cells: regulation of niche, self-renewal and differentiation. Arthritis Res Ther 2007;7:204.

24 Meirelles LdS, Caplan AI, Nardi NB: In search of the in vivo identity of mesenchymal stem cells. Stem Cells 2008;26:2287-2299.

25 Quinn C, Flake AW: In vivo differentiation potential of mesenchymal stem cells: prenatal and postnatal model systems. Transfus Med Hemother 2008; 35:239-247.

26 Kramer J, Böhrnsen F, Lindner U, Behrens P, Schlenke P, Rohwedel J: In vivo matrix-guided human mesenchymal stem cells. Cell Mol Life Sci 2006;63:616-626.

27 Friedenstein AJ, Chailakhjan RK, Lalykina KS: The development of fibroblast colonies in monolayer cultures of guinea-pig BM and spleen cells. Cell Tissue Kinet 1970;3:393-403.

28 Friedenstein AJ, Goskaja UF, Julagina NN: Fibroblast precursors in normal and irradiated mouse hematopoietic organs. Exp Hematol 1976;4:267-274.

29 Sacchetti B, Funari A, Michienzi S, Di Cesare S, Piersanti S, Saggio I, Tagliafico E, Ferrari S, Robey PG, Riminucci M, Bianco P: Self-renewing osteoprogenitors in bone marrow sinusoids can organize a hematopoietic microenvironment. Cell 2007;131:324-336.

30 Owen M: Lineage of osteogenic cells and their relationship to the stromal system; in Peck WA (ed): Bone and Mineral Research, vol. 3. New York Elsevier, 1985, pp 1-25.

31 Gronthos S, Simmons PJ: The Growth Factor Requirements of STRO-1-positive human BM stromal percusors under serum-deprived conditions in vitro. Blood 1995;85:929-940.

32 Kutnetsov SA, Friedenstein AJ, Robey PG: Factors required for bone-marrow stromal fibroblast colony formation in vitro. Br J Hematol 1997;97: $561-570$. 
-33 Baddoo D, Hill K, Wilkinson R, Gaupp D, Hughes C, Kopen GC, Phinney DG: Characterization of mesenchymal stem cells isolated from bone-marrow by negative selection. J Cell Biochem 2003;89: 1235-1249.

-34 Bianchi G, Banfi A, Mastrogiacomo M, Notaro R, Luzzatto L, Cancedda R, Quarto R: Ex vivo enrichment of mesenchymal stem cell progenitors by fibroblast growth factor 2. Exp Cell Res 2003;287: 98-105.

35 Wang QR, Yan ZJ, Wolf NS: Dissecting the hematopoietic microenvironment VI. The effects of several growth factors on the growth of murine bone marrow CFU-F. Exp Hematol 1990;18:341-347.

36 Caplan AI: Mesenchymal stem cells. J Orthop Res 1991;9:641-650.

37 Caplan AI: The Mesengenic Process. Clin Plast Surg 1994;21:429-435.

-38 Caplan AI: Osteogensis imperfecta, rehabilitation medicine, fundamental research and mesenchymal stem cells. Connect Tissue Res 1995;31:S9-14.

-39 Dominici M, LeBlanc K, Mueller I, Slaper-Cortenbach I, Marina F, Krause D, Deans R, Keating A, Prockop D, Horwitz E: Minimal criteria for defining mesenchymal stromal cells. The International Society for Cellular Therapy position statement. Cytotherapy 2006;8:315-317.

40 Haniffa MA, Collin MP, Buckley CD, Dazzi F: Mesenchymal stem cells: the fibroblasts' new clothes? Haematologica 2009;94:258-263.

41 Wagner W, Wein F, Seckinger A, Frankhauser M, Wirkner U, Krause U, Blake J, Schwager C, Eckstein V, Ansorge W, Ho AD: Comparative characteristics of mesenchymal stem cells from human bone marrow, adipose tissue, and umbilical cord blood. Exp Hematol 2005;33:1402-1416.

42 Wagner W, Ho AD: Mesenchymal stem cell preparations - comparing apples and oranges. Stem Cell Rev 2007;3:239-248.

43 Haniffa MA, Wang XN, Holtick U, Rae M, Isaacs JD, Dickinson AM, Hilkens CM, Collin MP: Adult human fibroblasts are potent immunoregulatory cells and functionally equivalent to mesenchymal stem cells. J Immunol 2007;179:1595-1604.

44 Huang HI, Chen SK, Ling QD, Chien CC, Liu HT, Chan SH: Multilineage differentiation potential of fibroblast-like stromal cells derived from human skin. Tissue Eng Part A; doi:10.1089/ten. tea.2009.0431.

45 Friedenstein AJ, Lalykina KS: Thymus cells are inducible to osteogenesis. Eur J Immunol 1972;6: 602-606.

46 Roufosse CA, Direkze NC, Otto WR, Wright NA: Circulating mesenchymal stem cells. Int J Biochem Cell Biol 2004;36:585-597.

47 Katz AJ, Tholpady A, Tholpady SS, Shang H, Ogle RC: Cell surface and transcriptional characterization of human adipose-derived adherent stromal (hADAS) cells. Stem Cells 2005;3:412-423.

48 Mitchell JB, McIntosh K, Zvonic S, Garrett S, Floyd ZE, Kloster A, Di Halvorsen Y, Storms RW, Goh B, Kilroy G, Wu X, Gimble JM: Immunophenotype of human mesenchymal stem cells cells: temporal changes in stromal-associated and stem cell-associated markers. Stem Cells 2006;24:376385.

49 Kilroy GE, Foster SJ, Wu X, Ruiz J, Sherwood S, Heifetz A, Ludlow JW, Stricker DM, Potiny S, Green P, Halvorsen YD, Cheatham B, Storms RW, Gimble JM: Cytokine profile of adult stem cells: expression of angiogenic, hematopoietic, and pro-inflammatory factors. J Cell Physiol 2007;212:702-709.
50 Rodriguez AM, Elabd C, Delteil F, Astier J, Vernochet C, Saint-Marc P, Guesnet J, Guezennec A, Amri EZ, Dani C, Ailhaud G: Adipocyte differentiation of multipotent cells established from human adipose tissue. Biochem Biophys Res Commun 2004:315:255-263.

51 Gimble JM, Dorheim MA, Cheng Q, Medina K, Wang CS, Jones R, Koren E, Pietrangeli C, Kincade PW: Adipogenesis in a murine BM stromal cell line capable of supporting B lineage lymphocyte growth and proliferation: bio-chemical and molecular characterization. Eur J Immunol 1990; 20:379-387.

52 Halvorsen YD, Bond A, Sen A, Franklin DM, Lea-Currie YR, Sujkowski D, Ellis PN, Wilkison WO, Gimble JM: Thiazolidinediones and glucocorticoids synergistically induce differentiation of human adipose tissue stromal cells: biochemical, cellular, and molecular analysis. Metabolism 2001; 50:407-413.

53 Sen A, Lea-Currie YR, Sujkowska D, Franklin DM, Wilkison WO, Halvorsen YD, Gimble JM: Adipogenic potential of human adipose derived stromal cells from multiple donors is heterogeneous. J Cell Biochem 2001;81:312-319.

54 Jaiswal N, Haynesworth SE, Caplan AI, Bruder SP: Osteogenic differentiation of purified, cultureexpanded human mesenchymal stem cells in vitro. J Cell Biochem 1997;64:295-312.

55 Heino TJ, Hentunen TA: Differentiation of osteoblasts and osteocytes from mesenchymal stem cells. Curr Stem Cell Res Ther 2008;2:131-145.

56 Chevallier N, Anagnostou F, Zilber S, Bodivit G, Maurin S, Barrault A, Bierling P, Hernigou P, Layrolle $\mathrm{P}$, Rouard $\mathrm{H}$ : Osteoblastic differentiation of human mesenchymal stem cells with platelet lysate. Biomaterials 2010;31:270-278.

57 Gronthos S, Graves SE, Ohta S, Simmons PJ: The STRO-1+ fraction of adult human BM contains the osteogenic precursors. Blood 1994;84:4164-4173.

58 Gronthos S, Zannettino AC, Graves SE, Ohta S, Hay SJ, Simmons PJ: Differential cell surface expression of the STRO-1 and alkaline phosphatase antigens on discrete developmental stages in primary cultures of human bone cells. J Bone Miner Res 1999;14:47-56.

59 Pelttari K, Steck E, Richter W: The use of mesenchymal stem cells for chondrogenesis. Injury 2008; 39(suppl 1):S58-65.

60 Erickson IE, Huang AH, Chung C, Li RT, Burdick JA, Mauck RL: Differential maturation and structure-function relationships in mesenchymal stem cell- and chondrocyte-seeded hydrogels. Tissue Eng Part A 2009;15:1041-1052.

61 Böhrnsen F, Lindner U, Meier M, Gadallah A, Schlenke P, Lehnert H, Rohwedel J, Kramer J: Murine mesenchymal progenitor cells from different tissues differentiated via mesenchymal microspheres into the mesodermal direction. BMC Cell Biol 2009;10:92.

62 Butler DL, Goldstein SA, Guilak F: Functional tissue engineering: the role of biomechanics. J Biomech Eng 2000;122:570-575

63 Shao XX, Hutmacher DW, Ho ST, Goh JC, Lee EH: Evaluation of a hybrid scaffold/cell construct in repair of high-load-bearing osteochondral defects in rabbits. Biomaterials 2006;27:1071-1080.

64 Betre H, Ong SR, Guilak F, Chilkoti A, Fermor B, Setton LA: Chondrocytic differentiation of human adipose-derived adult stem cells in elastin-like polypeptide. Biomaterials 2006;27:91-99.

65 Guilak F, Cohen DM, Estes BT, Gimble JM, Liedtke W, Chen CS: Control of stem cell fate by physical interactions with the extracellular matrix. Cell Stem Cell 2009;1:17-26.
66 Wang DW, Fermor B, Gimble JM, Awad HA, Guilak F: Influence of oxygen on the proliferation and metabolism of adipose derived adult stem cells. J Cell Physiol 2005;204:184-191.

67 Muraglia A, Cancedda R, Quarto R: Clonal mesenchymal progenitors from human bone marrow differentiate in vitro according to a hierarchical model. J Cell Sci 2000;113:1161-1166.

68 Bilkovski R, Schulte DM, Oberhauser F, Gomolka M, Udelhoven M, Hettich MM, Roth B, Heidenreich A, Gutschow C, Krone W, Laudes M: Role of wnt-5a in the determination of human mesenchymal stem cells into preadipocytes. J Biol Chem 2010;285:6170-6178.

69 Kim WK, Meliton V, Amantea CM, Hahn TJ, Parhami F: 20(S)-hydroxycholesterol inhibits PPARgamma expression and adipogenic differentiation of bone-marrow stromal cells through a hedgehogdependent mechanism. J Bone Miner Res 2007; 22:1711-1719.

70 Lecka-Czernik B, Moerman EJ, Grant DF, Lehmann JM, Manolagas SC, Jilka RL: Divergent effects of selective peroxisome proliferator-activated receptor-gamma 2 ligands on adipocyte versus osteoblast differentiation. Endocrinology 2002;143: 2376-2384.

71 Duque G, Rivas D: Alendronate has an anabolic effect on bone through the differentiation of mesenchymal stem cells. J Bone Miner Res 2007;10: 1603-1611.

72 Bowers RR, Lane MD: A role for bone morphogenetic protein-4 in adipocyte development. Cell Cycle 2007;6:385-389.

73 Rojewski MT, Weber BM, Schrezenmeier H: Phenotyping characterization of mesenchymal stem cells from various tissues. Transfus Med Hemother 2008;35:168-184.

74 Pontikoglou C, Delorme B, Charbord P: Human bone-marrow native mesenchymal stem cells. Regen Med 2008;5:731-741.

75 Bühring HJ, Treml S, Cerabona F, de Zwart P, Kanz L, Sobiesiak M: Phenotypic characterization of distinct human bone-marrow-derived MSC Subsets. Annu N Y Acad Sci 2009;1176:124-134.

76 Jones EA, English A, Kinsey SE, Straszynski L, Emery P, Ponchel F, McGonagle D: Optimization of a flow cytometry-based protocol for detection and phenotypic characterization of multipotent mesenchymal stromal cells from human BM. Cytometry B Clin Cytom 2006;70:391-399.

77 Quirici N, Soligo D, Bossolasco P, Servida F, Lumini C, Deliliers GL: Isolation of bone marrow mesenchymal stem cells by anti-nerve growth factor receptor antibodies. Exp Hematolol 2002;7:783-791.

78 Morrison SJ, Uchida N, Weissman IL: The biology of hematopoietic stem cells. Annu Rev Cell Dev Biol 1995;11:35-71.

79 Clark BR, Jamieson C, Keating A: Human longterm bone-marrow culture. Methods Mol Biol 1997 75:249-256.

80 Bianco P, Robey PG: Stem cells in tissue engineering. Nature 2001;414:118-121.

81 Bianco P, Riminucci M, Gronthos S, Robey PG: Bone-marrow stromal stem cells: nature, biology, and potential applications. Stem Cells 2001;19:180-192.

82 Bianco P, Robey PG, Simmons PJ: Mesenchymal stem cells: revisiting history, concepts, and assay. Cell Stem Cell 2009;2,313-319.

83 Horwitz EM, Le Blanc K, Dominici M, Mueller I, Slaper-Cortenbach I, Marini FC, Deans RJ, Krause DS, Keating A; International Society for Cellular Therapy: Clarification of the nomenclature for MSC: the International Society for Cellular Therapy position statement. Cytotherapy 2005;7:393-395. 
84 Dellavalle A, Sampaolesi M, Tonlorenzi R, Tagliafico E, Sacchetti B, Perani L, Innocenzi A Galvez BG, Messina G, Morosetti R, Li S, Belicchi M, Peretti G, Chamberlain JS, Wright WE, Torrente Y, Ferrari S, Bianco P, Cossu G: Pericytes of human skeletal muscle are myogenic precursors distinct from satellite cells. Nature Cell Biol 2007; 9:255-267.

85 Gronthos S, Franklin DM, Leddy HA, Robey PG Storms RW, Gimble JM: Surface protein characterization of human adipose tissue-derived stromal cells. J Cell Physiol 2001;189:54-63.

86 Rodriguez AM, Elabd C, Amri EZ, Ailhaud G, Dani C: The human adipose tissue is a source of multipotent stem cells. Biochemie 2005;1:125-128.

87 Lindroos B, Boucher S, Chase L, Kuokkanen H, Huhtala H, Haataja R, Vemuri M, Suuronen R, Miettinen S: Serum-free, xeno-free culture media maintain the proliferation rate and multipotentiality of adipose stem cells in vitro. Cytotherapy 2009 ; 11:958-972.

88 Schreml S, Babilas P, Fruth S, Orsó E, Schmitz G, Mueller MB, Nerlich M, Prantl L: Harvesting human adipose tissue-derived adult stem cells: resection versus liposuction. Cytotherapy 2009;11: 947-957.

89 Sensebé L, Bourin P: Mesenchymal stem cells for therapeutic purposes. Transplantation 2009;15 (9 suppl):S49-53.

90 Alsalameh S, Amin R, Gemba T, Lotz M: Identification of mesenchymal progenitor cells in normal and osteoarthritic human articular cartilage. Arthritis Rheum 2004;5:1522-1532.

91 Hiraoka K, Grogan S, Olee T, Lotz M: Mesenchymal progenitor cells in adult human articular cartilage. Biorheology 2006;43:447-454.

92 Secco M, Moreira YB, Zucconi E, Vieira NM, Jazedje T, Muotri AR, Okamoto OK, VerjovskiAlmeida S, Zatz M: Gene expression profile of mesenchymal stem cells from paired umbilical cord units: cord is different from blood. Stem Cell Rev 2009;5,387-401.

-93 Jäger M, Zilkens C, Bittersohl B, Krauspe R: Cord blood - an alternative source for bone regeneration. Stem Cell Rev 2009;5: 266-277.

94 Bieback K, Klüter H: Mesenchymal stromal cells from umbilical cord blood. Curr Stem Cell Res Ther 2007;2:310-323.
95 Campagnoli C, Roberts IA, Kumar S, Bennett PR, Bellantuono I, Fisk NM: Identification of mesenchymal stem/progenitor cells in human first-trimester fetal blood, liver, and bone marrow. Blood 2001;8,2396-2402.

96 Nakamura S, Yamada Y, Katagiri W, Sugito T, Ito K, Ueda M: Stem cell proliferation pathways comparison between human exfoliated deciduous teeth and dental pulp stem cells by gene expression profile from promising dental pulp. J Endod 2009; 11:1536-1542.

97 Huang GT, Gronthos S, Shi S: Mesenchymal stem cells derived from dental tissues vs. those from other sources: their biology and role in regenerative medicine. J Dent Res 2009;9:792-806.

98 Valtieri M, Sorrentino A: The mesenchymal stromal cell contribution to homeostasis. J Cell Physiol 2008;296:296-300.

99 Shi S, Bartold PM, Miura M, Seo BM, Robey PG, Gronthos S: The efficacy of mesenchymal stem cells to regenerate and repair dental structures. Orthod Craniofac Res 2005;3:191-199.

100 O'Driscoll SW, Fitzsimmons JS: The role of periosteum in cartilage repair. Clinical Orthop Relat Res 2001;(391 suppl):S190-207.

101 de Mos M, Koevoet WJ, Jahr H, Verstegen MM, Heijboer MP, Kops N, van Leeuwen JP, Weinans $\mathrm{H}$, Verhaar JA, van Osch GJ: Intrinsic differentiation potential of adolescent human tendon tissue: an in-vitro cell differentiation study. BMC Musculoskelet Disord 2007;8:16.

102 Meirelles Lda S, Nardi NB: Methodology, biology and clinical applications of mesenchymal stem cells. Front Biosci 2009;14:4281-4298.

103 Rodríguez JP, Astudillo P, Ríos S, Pino AM: Involvement of adipogenic potential of human BM mesenchymal stem cells (MSCs) in osteoporosis. Curr Stem Cell Res Ther 2008;3:208-218.

104 Rickard DJ, Wang FL, Rodriguez-Rojas AM, Wu Z, Trice WJ, Hoffman SJ, Votta B, Stroup GB, Kumar S, Nuttall ME: Intermittent Treatment with parathyroid hormone (PTH) as well as a non-peptide small molecule agonist of the PTH1 receptor inhibits adipocyte differentiation in human bone marrow stromal cells. Bone 2006;39:1361-1372.
105 Chen WH, Lai MT, Wu AT, Wu CC, Gelovani JG, Lin CT, Hung SC, Chiu WT, Deng WP: In vitro stage-specific chondrogenesis of mesenchymal stem cells committed to chondrocytes. Arthritis Rheum 2009;60:450-459.

06 Djouad F, Mrugala D, Noël D, Jorgensen C: Engineered mesenchymal stem cells for cartilage repair. Regen Med 2006;1:529-537.

107 Santiago JA, Pogemiller R, Ogle BM: Heterogeneous differentiation of human mesenchymal stem cells in response to extended culture in extracellular matrices. Tissue Eng Part A 2009;15: 3911-3922.

108 Song IH, Caplan AI, Dennis JE: In vitro dexamethasone pretreatment enhances bone formation of human mesenchymal stem cells in vivo. J Orthop Res 2009;27:916-921.

109 Kassem M, Abdallah BM, Saeed H: Osteoblastic cells: differentiation and trans-differentiation. Arch Biochem Biophys 2008;473:183-187.

110 Meirelles Lda S, Nardi MB: Murine marrow derived mesenchymal stem cell: isolation, in vitro expansion, and characterization. Br J Hematol 2003; 123:702-711.

111 Vogel W, Grünebach F, Messam CA, Kanz L, Brugger W, Bühring HJ: Heterogeneity among human BM-derived mesenchymal stem cells and neural progenitor cells. Haematologica 2003;88: 126-133.

112 Verfaillie CM: Anatomy and physiology of hematopoiesis; in Hoffman R, Strauss M, Benz EJJ, et al (eds): Hematology - Basic Principles and Practice, 3rd ed. Philadelphia, Churchill-Livingstone, 2000, pp 139-154.

113 Buhring HJ, Battula VL, Trml S, Schewe, B, Kanz L, Vogel W: Novel markers for the prospective isolation of human MSC. Annu N Y Acad Sci 2007; 1106:262-271.

114 Schäfer R: Labeling and imaging of stem cells promises and concerns. Transfus Med Hemother 2010;37(2):85-89.

115 Freimark D, Pino-Grace P, Pohl S, Weber C, Wallrapp C, Geigle P, Pörtner R, Czermak P: Use of encapsulated stem cells to overcome the bottleneck of cell availability for cell therapy approaches. Transfus Med Hemother 2010;37(2) 66-73. 